\title{
Zedoary oil (Ezhu You) inhibits proliferation of AGS cells
}

\author{
Hailian Shi ${ }^{1,2,3}$, Bao Tan ${ }^{4}$, Guang Ji $i^{1}$, Lan Lü ${ }^{2,3}$, Aili Cao ${ }^{2,3}$, Songshan Shi ${ }^{2}$ and Jianqun Xie ${ }^{{ }^{*}}$
}

\begin{abstract}
Background: Zedoary (Curcumae Rhizoma, Ezhu), a Chinese medicinal herb, has been reported to show anticancer activity. This study aims to investigate the effect of zedoary oil (Ezhu You) on the proliferation of AGS cells which is one gastric cancer cell line.

Methods: The main ingredients of the herb were detected by GC-MS for herbal quality control. Cell viability was measured by MTT assay and cell proliferation was investigated by immunocytochemical staining for proliferating cell nuclear antigen (PCNA) protein. In addition, the cell cycle distributions were detected by flow cytometry with propidium iodine (PI) staining and the apoptosis rates were evaluated by flow cytometry with annexin V/PI double-staining. The morphological changes associated with apoptosis were observed by Hoechst 33342/PI double-staining. Protein expression was determined by western blot analysis.
\end{abstract}

Results: The main ingredients of the herb, including curzerene (26.45\%), eucalyptol (12.04\%), curcumol (9.04\%), pyridine (7.97\%), germacrone (7.89\%), $\beta$-elemene (7.36\%), t-elemene (4.11\%) and 28 other ingredients, including curdione, were consistent with the chemical profiles of zedoary. Zedoary oil significantly decreased the cell viability of AGS cells $(P<0.01)$ and MGC 803 cells $(P<0.01)$, and the inhibitory effects were attenuated by elevated concentrations of FBS. At high concentrations ( $\geq 90 \mu \mathrm{g} / \mathrm{mL}$ ), zedoary oil killed GES-1 cells. At low concentrations ( $\leq 60 \mu \mathrm{g} / \mathrm{mL}$ ), zedoary oil was less inhibitory toward normal gastric epithelial cells than gastric cancer cell lines. In AGS cells, zedoary oil inhibited cell proliferation in a dose- and time-dependent manner, with decreased PCNA protein expression in the zedoary oiltreated cells, and arrested the cell cycle at $S, G_{2} / M$ and $G_{0} / G_{1}$ stages after treatment for $6-48$ h. At concentrations of 30, 60 and $90 \mu \mathrm{g} / \mathrm{mL}$, which resulted in significant inhibition of proliferation and cell cycle arrest, zedoary oil induced cell apoptosis. In addition, Hoechst 33342/PI double-staining confirmed the morphological characteristics of cell apoptosis at $24 \mathrm{~h}$. Zedoary oil upregulated the ratio of Bax/BCl-2 protein expression $(P<0.01)$.

Conclusions: Zedoary oil inhibited AGS cell proliferation through cell cycle arrest and cell apoptosis promotion, which were related to $\mathrm{Bax} / \mathrm{BCl}-2$ protein expression.

\section{Background}

Curcuma phaeocaulis, Curcuma kwangsiensis and Curcuma wenyujin are named zedoary in the Chinese Pharmacopoeia and used as antiviral and antimicrobial medicines [1-3]. Zedoary oil is a Chinese medicine that is used for treatment of gynecologic inflammation [4], pneumonia [5], pediatric diseases [6], viral myocarditis [7] and malignant tumors, such as oophoroma, hepatocellular carcinoma and lung

\footnotetext{
* Correspondence: xiejianqun@live.cn

${ }^{1}$ Institute of Digestive Disease, Longhua Hospital, Shanghai University of Traditional Chinese Medicine, 725 South Wanping Road, XuHui District, Shanghai 200032, PR China

Full list of author information is available at the end of the article
}

cancer [8-11]. Moreover, zedoary oil is a safe drug with low toxicity [12]. Deng et al. [13] reported that the acute toxicity of zedoary turmeric oil gelatin microspheres might result from dystopic embolism rather than the zedoary turmeric oil itself entrapped in the microspheres.

Zedoary belongs to the Zingiberacea family, which is composed of about 70 species of rhizomatous herbs at home and abroad, with approximately 20 species existing in China $[1,10]$. Different species of zedoary and different preparations have different chemical ingredients [14], which result in different biological actions. Many chemical analysis methods, including thin-layer chromatography scanning, high-performance liquid chromatography, gas chromatography (GC) and gas chromatography-mass spectrometry

\section{Biomed Central}


(GC-MS), are used to detect the chemical compounds in essential oil of zedoary and also for quality control [15].

Gastric glandular cells are replaced by intestinal-type epithelial cells with high cell proliferation rates and fibrosis in severe inflammation of the gastric membrane, resulting in chronic atrophic gastritis with intestinal metaplasia and dysplasia, imbalance between cell proliferation and apoptosis in the normal gastric mucosa and increasing incidence of gastric cancer [16-19].

Proliferating cell nuclear antigen (PCNA) was originally identified as an antigen expressed in the nuclei of cells during the DNA synthesis phase of the cell cycle [20], and only exists in normal proliferative cells and cancer cells.

Bax and Bcl-2 are very important for cytochrome cdependent apoptosis. Bax inserts itself into the outer mitochondrial membrane, followed by cytochrome c release from mitochondria. In contrast, when Bcl-2 binds to the outer mitochondrial membrane, the release of cytochrome c is blocked [21,22]. Many anticancer agents can induce release of cytochrome $\mathrm{c}$ by upregulating Bax expression and/or downregulating Bcl-2 expression [23-25].

Chinese medicines are available for treatment of patients with chronic atrophic gastritis [26]. Zedoarycontaining Chinese herbal formulas, e.g., Weiqi decoction (an empirical formula from Longhua Hospital, Shanghai University of Traditional Chinese Medicine, China), are often used for treatment of gastric diseases [27-29]. However, the effects of zedoary oil on gastric epithelial cells with high proliferation rates are unclear.

The AGS cell line, a type of human gastric cancer epithelial cell line, is used as a cell model for abnormal proliferation and apoptosis in the gastric mucosa and gastric cancer research $[30,31]$. The present study aims to investigate the effect of zedoary oil (Ezhu You) on AGS cell proliferation.

\section{Methods \\ Materials}

Zedoary oil was purchased from Shanghai Institute for the National Institute for the Control of Pharmaceutical and Biological Products (Lot No. 111544-200703) (Shanghai, China). AGS (TCHu 7) and MGC 803 (TCHu 84) cell lines were purchased from Cell Bank of Academia Sinica (Shanghai, China). The GES-1 cell line was purchased from Cell Bank of Chinese Academy of Medical Sciences (Beijing, China). Ham's/F-12, DMEM/High Glucose and RPMI 1640 media were purchased from Thermo Fisher Scientific Inc. (IL, USA). Fatal bovine serun (FBS) was purchased from Hangzhou Sijiqing Biological Engineering Materials Co. Ltd. (Hangzhou, China). FBS (Lot No. 989268) was purchased from Gibco (NY, USA). DMSO (Lot No. 1988B176) was purchased from Amresco (OH, USA). MTT (Lot No. 091205) was purchased from Richu BioScience Co. Ltd.
(Shanghai, China). PI (Lot No. 118 K3538) and DMSO (Lot No. 019 K2300) were purchased from Sigma Chemical Co. (MO, USA). A Hoechst 33342/PI Apoptosis/death Staining Kit (Catalogue No. C1056) and Hematoxylin Staining Kit (Catalogue No. C0107) were purchased from Beyotime (Shanghai, China). Trypsin (Lot No. 632461) was purchased from Invitrogen (CA, USA). RNase A (Lot No. 3408B040) was purchased from Beijing Jingkehongda Biotech. Co. Ltd. (Beijing, China). Annexin V (Lot No. 40601) was purchased from BioVision Inc. (CA, USA). Anti-Bax (Lot No. 4), anti-Bcl-2 (Lot No. 2) and anti- $\beta$-actin (Lot No. 3) antibodies were purchased from Cell Signaling Technology (MA, USA). An anti-PCNA (Lot No. YJ020304CS) antibody was purchased from Epitomics (CA, USA). An $\mathrm{S}_{\mathrm{ABC}}$ Kit (Lot No. 06L06AJ) and a DAB Kit (Catalogue No. AR1022) were purchased from Wuhan Boster Biological Technology Co. Ltd. (Wuhan, China). An ECL plus Kit (Lot No. 84A) was purchased from GE Healthcare (NA, UK). Cell plates were purchased from Greiner BioOne (Frickenhausen, Germany). Syringe filters were purchased from Pall Co. Ltd. (MI, USA).

\section{Identification of the main constituents in zedoary oil by GC-MS analysis}

Zedoary oil was diluted with chloroform at a ratio of 1:1000. The analysis was performed on a Thermo Scientific system composed of a DSQ mass spectrometer coupled with a Trace GC Ultra gas chromatograph and an AS 3000 autosampler (Thermo Scientific, USA). The GC was equipped with a $30-\mathrm{m}$ (0.25-mm internal diameter; $0.25-\mu \mathrm{m}$ film thickness) TR-5MS fused-silica capillary column (Thermo Scientific). The splitless injection port temperature was set at $250^{\circ} \mathrm{C}$. The column temperature program was $50^{\circ} \mathrm{C}$ for $1 \mathrm{~min}$, followed by elevation to $110^{\circ} \mathrm{C}$ at $5^{\circ} \mathrm{C} / \mathrm{min}$, $140^{\circ} \mathrm{C}$ at $3^{\circ} \mathrm{C} / \mathrm{min}$ and $170^{\circ} \mathrm{C}$ at $5^{\circ} \mathrm{C} / \mathrm{min}$. Finally, the temperature was raised to $230^{\circ} \mathrm{C}$ at $3^{\circ} \mathrm{C} / \mathrm{min}$ and held at $230^{\circ} \mathrm{C}$ for $5 \mathrm{~min}$. The constant flow rate was $1 \mathrm{~mL} / \mathrm{min}$ He. The MS was operated in the positive EI mode. The ion source temperature was set at $250^{\circ} \mathrm{C}$. The peaks were identified by comparisons with The National Institute of Standards and Technology (NIST) library. Relative quantitative data were obtained from the normalized peak areas: $\%$ area = $($ area/total area $) \times 100$.

\section{Cell culture}

AGS cells, MGC 803 cells (gastric cancer cell line) and GES-1 cells (normal gastric epithelial cells) were cultured in Ham's/F-12, RPMI 1640 and DMEM media supplemented with $10 \% \mathrm{FBS}$, respectively, at $37^{\circ} \mathrm{C}$ in a $5 \% \mathrm{CO}_{2}$ atmosphere. 


\section{Proliferation assay}

Cells were seeded in 96-well culture plates at a density of $1.0 \times 10^{4}$ cells $/ \mathrm{mL}$ in $200 \mu \mathrm{L}$ of medium and allowed to adhere to the plates overnight. The cells were then treated with a range of concentrations $(0-300 \mu \mathrm{g} / \mathrm{mL})$ of zedoary oil or $0.1 \%$ DMSO for 24,48 or $72 \mathrm{~h}$. Subsequently, $20 \mu \mathrm{L}$ of MTT was added to each well and incubated at $37^{\circ} \mathrm{C}$ for $4 \mathrm{~h}$. After removal of the medium and MTT, $150 \mu \mathrm{L}$ of DMSO was added to each well and shaken for $15 \mathrm{~min}$ to completely dissolve the formazan crystals. Finally, the absorbances at $570 \mathrm{~nm}$ of the dissolved solutions were detected using a SpectraMAX 190 microplate reader (Molecular Devices, USA). The cell viability rate was calculated using the following equation: rate $\%)=($ treated absorbance/untreated absorbance) $\times 100$. The effects of three compounds in zedoary oil, namely beta-elemene, curcumol and curdione, on the proliferation of AGS cells were also investigated.

\section{Immunocytochemical staining for PCNA protein}

After treatment with zedoary oil for $24 \mathrm{~h}$, AGS cells were washed with $1 \times$ PBS, and fixed in $4 \%$ paraformaldehyde for $20 \mathrm{~min}$. The cell membranes were permeated with $0.5 \%$ Triton $\mathrm{X}-100(\mathrm{pH} 7.4)$ for $20 \mathrm{~min}$ at room temperature followed by incubation with $3 \% \mathrm{H}_{2} \mathrm{O}_{2}$ for $15 \mathrm{~min}$. After blocking with $5 \% \mathrm{BSA}$ for $20 \mathrm{~min}$ at $37^{\circ} \mathrm{C}$, the cells were incubated with a rabbit anti-PCNA monoclonal antibody and visualized using the $\mathrm{S}_{\mathrm{ABC}}$ Kit and DAB Kit. The cell nuclei were stained with hematoxylin. Finally, coverslips were placed on the glass slides on a drop of mounting medium, and the cells were photographed under a microscope (Olympus CKX41, Japan).

\section{Cell cycle distribution analysis}

Cells were plated in 6-well culture plates at a density of $2.0 \times 10^{4}$ cells $/ \mathrm{mL}$ in $3 \mathrm{~mL}$ of medium and allowed to adhere to the plates overnight. Subsequently, the medium containing $10 \%$ FBS was removed and the same volume of medium without FBS was added for $24 \mathrm{~h}$. The cells were then incubated with a range of concentrations $(30,60$ and $90 \mu \mathrm{g} / \mathrm{mL}$ ) of zedoary oil or $0.1 \%$ DMSO in medium containing $10 \%$ FBS for $6,12,24$ or $48 \mathrm{~h}$. After the treatments, the cells were harvested by trypsinization, washed twice with PBS, fixed overnight with $70 \%$ cold ethanol and stained with PI solution containing $50 \mu \mathrm{g} / \mathrm{mL}$ RNase $\mathrm{A}$ and $0.1 \%$ Triton X-100. The cell cycle distributions were detected using a FACScan flow cytometer (Becton Dickinson, USA), and the data were analyzed by ModFitLT V3.0 software (Becton Dickinson).

\section{Cell apoptosis/necrosis detection by annexin V/PI double-staining}

Cells were plated in 6-well culture plates at a density of $2.5 \times 10^{4}$ cells $/ \mathrm{mL}$ in $3 \mathrm{~mL}$ of medium and allowed to adhere to the plates overnight. Next, the medium containing 10\% FBS was removed and the same volume of medium without FBS was added for $24 \mathrm{~h}$. The cells were then incubated with a range of concentrations $(60,90$ and $120 \mu \mathrm{g} / \mathrm{mL}$ ) of zedoary oil in medium containing 10\% FBS for $24 \mathrm{~h}$. After the treatments, the cells were harvested by careful trypsinization, washed twice with $1 \times$ annexin $\mathrm{V}$

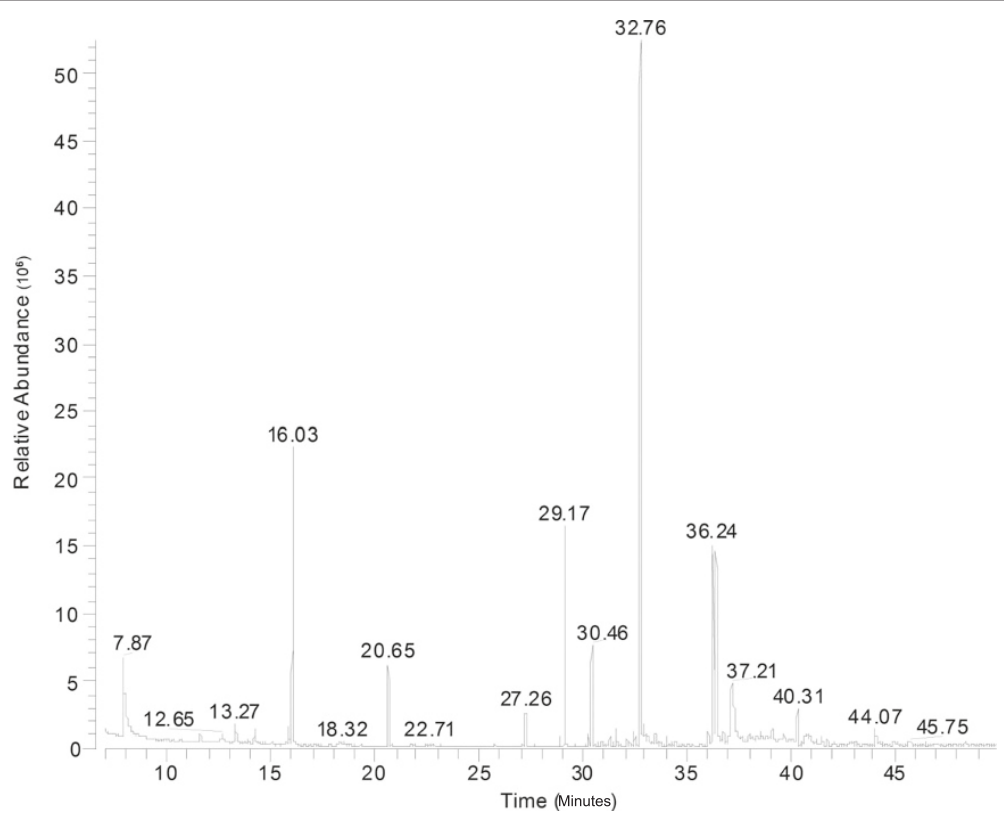

Figure $1 \mathrm{GC}-\mathrm{MS}$ spectrum of zedoary oil. 
binding buffer, resuspended in binding buffer and stained with annexin V and PI. Cell apoptosis was detected using the FACScan flow cytometer.

\section{Apoptosis and necrosis detection by Hoechst 33342/PI double-staining}

Cells were seeded in 6-well culture plates at a density of $2.0 \times 10^{4}$ cells $/ \mathrm{mL}$ in $3 \mathrm{~mL}$ of medium and allowed to

Table 1 Compounds detected in the zedoary oil

\begin{tabular}{|c|c|c|c|}
\hline $\begin{array}{l}\text { Apex } \\
\text { RT }\end{array}$ & $\begin{array}{l}\text { Area } \\
(\%)\end{array}$ & Composition & AS No. \\
\hline 7.87 & 7.97 & pyridine & $110-86-1$ \\
\hline 11.58 & 0.45 & 1,1-ethanediol diacetate & $542-10-9$ \\
\hline 12.65 & 0.67 & a-pinene & $80-56-8$ \\
\hline 13.27 & 1.18 & camphene & $79-92-5$ \\
\hline 13.91 & 0.21 & sabinene & $3387-41-5$ \\
\hline 14.19 & 0.95 & $\beta$-pinene & $127-91-3$ \\
\hline 15.82 & 0.73 & bornylene & $464-17-5$ \\
\hline 16.03 & 12.04 & eucalyptol & $470-82-6$ \\
\hline 20.65 & 3.18 & (-)-alcanfor & $464-48-2$ \\
\hline 27.26 & 1.05 & $\delta$-elemene & 20307-84-0 \\
\hline 29.17 & 7.36 & $\beta$-elemene & 515-13-9 \\
\hline 30.29 & 0.66 & $\beta$-cubebene & $13744-15-5$ \\
\hline 30.46 & 4.11 & t-elemene & $30824-67-0$ \\
\hline 30.72 & 0.13 & $\beta$-cubebene & $13744-15-5$ \\
\hline 31.3 & 0.27 & $\gamma$-muurolene & $30021-74-0$ \\
\hline 31.44 & 0.16 & $\gamma$-cadinene & $39029-41-9$ \\
\hline 31.63 & 0.6 & a-caryophyllene & $6753-98-6$ \\
\hline 32.09 & 0.31 & & \\
\hline 32.24 & 0.07 & & \\
\hline 32.43 & 0.42 & germacrene-D & $23986-74-5$ \\
\hline 32.51 & 0.26 & zingiberene & $495-60-3$ \\
\hline 32.76 & 26.45 & curzerene & 17910-09-7 \\
\hline 32.96 & 0.39 & a-selinene & $473-13-2$ \\
\hline 33.45 & 0.35 & $\beta$-cadinene & $523-47-7$ \\
\hline 34.02 & 0.34 & $(+)$ - $\beta$-guaiene & $88-84-6$ \\
\hline 36.24 & 7.89 & germacrone & $6902-91-6$ \\
\hline 36.39 & 7.63 & & \\
\hline 36.78 & 0.36 & & \\
\hline 37.21 & 9.04 & curcumol & $4871-97-0$ \\
\hline 39.1 & 0.41 & butylidenephtalide & $551-08-6$ \\
\hline 40.31 & 1.23 & curdione & $13657-68-6$ \\
\hline 41.24 & 0.11 & & \\
\hline 41.53 & 0.24 & & \\
\hline 41.74 & 0.23 & & \\
\hline 44.07 & 1.13 & $\begin{array}{l}\text { 2-[(4-methoxyphenyl)methylene]- } \\
\text { Cyclohexanone }\end{array}$ & $5765-29-7$ \\
\hline
\end{tabular}

adhere to the plates overnight. The medium containing $10 \%$ FBS was removed and the same volume of medium without FBS was added for $24 \mathrm{~h}$. The cells were then incubated with a range of concentrations $(30,60$ and $90 \mu \mathrm{g} / \mathrm{mL})$ of zedoary oil or $0.1 \%$ DMSO in medium containing $10 \%$ FBS for $24 \mathrm{~h}$. After the treatments, the cells were harvested by careful trypsinization and resuspended in staining buffer. The cells were stained with Hoechst 33342 and PI, and analyzed for apoptosis and/or necrosis under a fluorescence microscope (Olympus CKX41, Japan). The rates of Hoechst 33342-positive cells, whose blue color was brilliant and aggregative, were analyzed by Image-Pro Plus 6.0 software (Media Cybernetics, USA).

\section{Western blot analysis}

Cells were plated in 6-well culture plates at a density of $4.0 \times 10^{4}$ cells $/ \mathrm{mL}$ in $3 \mathrm{~mL}$ of medium and allowed to adhere to the plates overnight. The medium containing $10 \%$ FBS was removed and the same volume of medium without FBS was added for $24 \mathrm{~h}$. The cells were then incubated with a range of concentrations $(60,90$ and $120 \mu \mathrm{g} / \mathrm{mL})$ of zedoary oil or $0.1 \%$ DMSO in medium containing $10 \%$ FBS for $24 \mathrm{~h}$. After the incubations, the cells were collected, lysed with cell lysis buffer and sonicated three times for $15 \mathrm{~s}$ each. The cell lysates were centrifuged for $15 \mathrm{~min}$ at $14,000 \times g$ and $4^{\circ} \mathrm{C}$, and the supernatants were collected. The protein samples were separated by SDSPAGE (15\% separating gel and 5\% stacking gel) and

Table 2 Effects of zedoary oil and $\beta$-elemene on cell viability

\begin{tabular}{|c|c|c|c|c|}
\hline \multirow[t]{2}{*}{ Group } & \multirow[t]{2}{*}{$\mathrm{n}$} & \multicolumn{3}{|c|}{ Cell viability } \\
\hline & & $24 \mathrm{~h}$ & $48 \mathrm{~h}$ & $72 \mathrm{~h}$ \\
\hline \multicolumn{5}{|l|}{ Zedoary oil } \\
\hline $0 \mu \mathrm{g} / \mathrm{mL}$ & 4 & $99.5 \pm 0.9$ & $99.8 \pm 0.3$ & $99.9 \pm 0.2$ \\
\hline $1 \mu \mathrm{g} / \mathrm{mL}$ & 4 & $95.8 \pm 2.9$ & $82.5 \pm 2.5^{* *}$ & $71.0 \pm 7.0^{* *}$ \\
\hline $10 \mu \mathrm{g} / \mathrm{mL}$ & 4 & $95.0 \pm 2.3$ & $77.1 \pm 6.2^{* *}$ & $69.2 \pm 2.3^{* *}$ \\
\hline $30 \mu \mathrm{g} / \mathrm{mL}$ & 4 & $81.2 \pm 6.2^{* *}$ & $74.3 \pm 3.5^{* *}$ & $58.4 \pm 2.9^{* *}$ \\
\hline $60 \mu \mathrm{g} / \mathrm{mL}$ & 4 & $65.3 \pm 5.1^{* *}$ & $49.5 \pm 4.2^{* *}$ & $42.5 \pm 5.4^{* *}$ \\
\hline $90 \mu \mathrm{g} / \mathrm{mL}$ & 4 & $47.4 \pm 1.5^{* *}$ & $19.0 \pm 3.6^{* *}$ & $16.7 \pm 5.9^{* *}$ \\
\hline $100 \mu \mathrm{g} / \mathrm{mL}$ & 4 & $35.4 \pm 4.7^{* *}$ & $13.7 \pm 9.4^{* *}$ & $9.8 \pm 5.7^{* *}$ \\
\hline $300 \mu \mathrm{g} / \mathrm{mL}$ & 4 & $14.8 \pm 2.5^{* *}$ & $5.3 \pm 0.6^{* *}$ & $2.5 \pm 0.7^{* *}$ \\
\hline \multicolumn{5}{|l|}{$\beta$-elemene } \\
\hline $11.5 \mu \mathrm{g} / \mathrm{mL}$ & 3 & $98.2 \pm 2.0$ & $98.1 \pm 10.7$ & $91.2 \pm 7.4$ \\
\hline $23 \mu \mathrm{g} / \mathrm{mL}$ & 4 & $97.1 \pm 5.0$ & $89.0 \pm 8.5$ & $86.8 \pm 14.4$ \\
\hline $92 \mu \mathrm{g} / \mathrm{mL}$ & 4 & $94.1 \pm 6.8$ & $81.6 \pm 3.1^{*}$ & $79.6 \pm 3.5^{*}$ \\
\hline $184 \mu \mathrm{g} / \mathrm{mL}$ & 4 & $87.6 \pm 2.0$ & $60.3 \pm 9.5^{* *}$ & $70.0 \pm 9.1^{* *}$ \\
\hline $368 \mu \mathrm{g} / \mathrm{mL}$ & 4 & $25.1 \pm 2.4^{* *}$ & $14.0 \pm 6.3^{* *}$ & $12.0 \pm 3.4^{* *}$ \\
\hline $1104 \mu \mathrm{g} / \mathrm{mL}$ & 4 & $9.3 \pm 1.3^{* *}$ & $3.2 \pm 0.7^{* *}$ & $5.0 \pm 4.1^{* *}$ \\
\hline
\end{tabular}

AGS cells were treated with zedoary oil in Ham's/F-12 medium containing $10 \%$ FBS for 24,48 and $72 \mathrm{~h}$. The cell viability was detected by MTT assays. ${ }^{*} P<0.05$, ${ }^{*} P<0.01$ vs. control cells. 
A

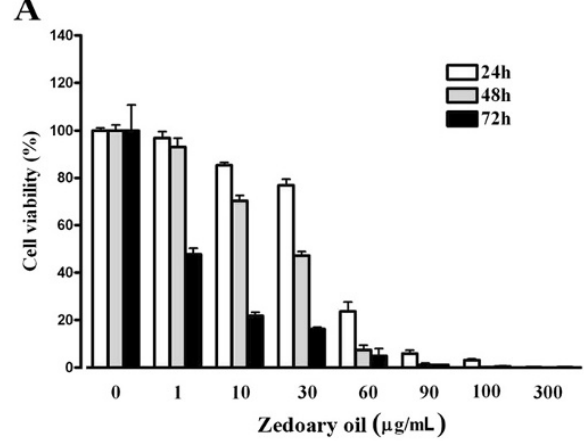

C

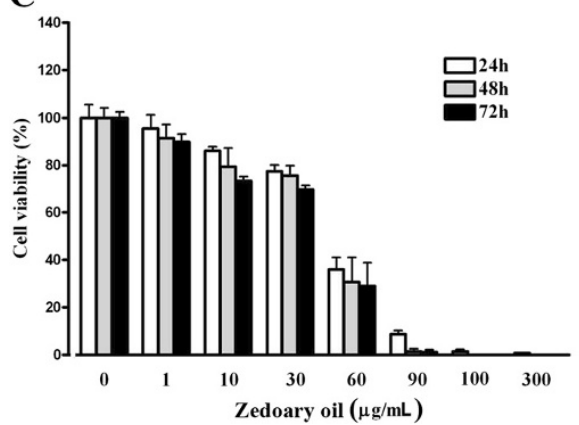

B

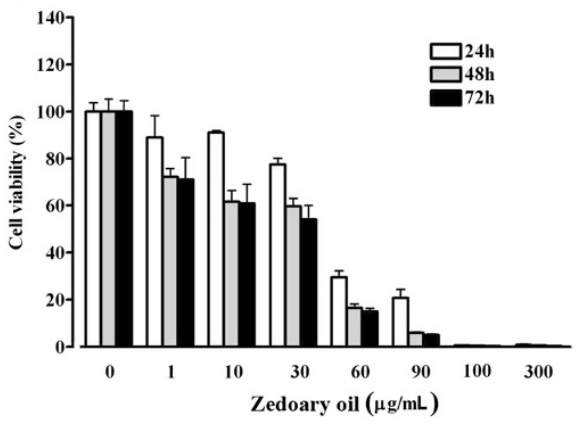

D

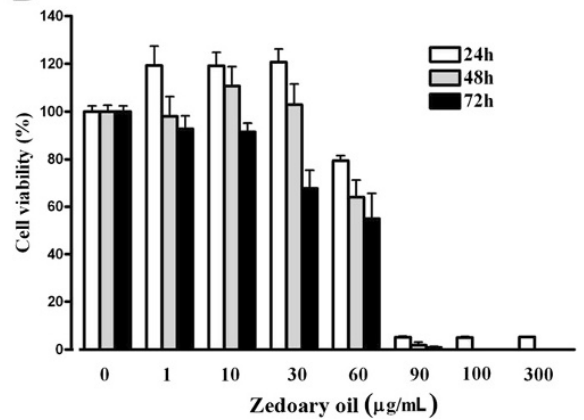

Figure 2 Effects of zedoary oil on the viability of gastric cancer cells and normal gastric epithelial cells. (A) AGS cells were treated with zedoary oil without FBS for 24, 48 and 72 h. (B) AGS cells were treated with zedoary oil containing 3\% FBS for 24, 48 and 72 h. (C) MGC 803 cells were treated with zedoary oil containing $3 \%$ FBS for 24,48 and 72 h. (D) GES-1 cells were treated with zedoary oil containing $3 \%$ FBS for 24,48 and $72 \mathrm{~h}$. Data represent means \pm SD $(\mathrm{N}=3)$.

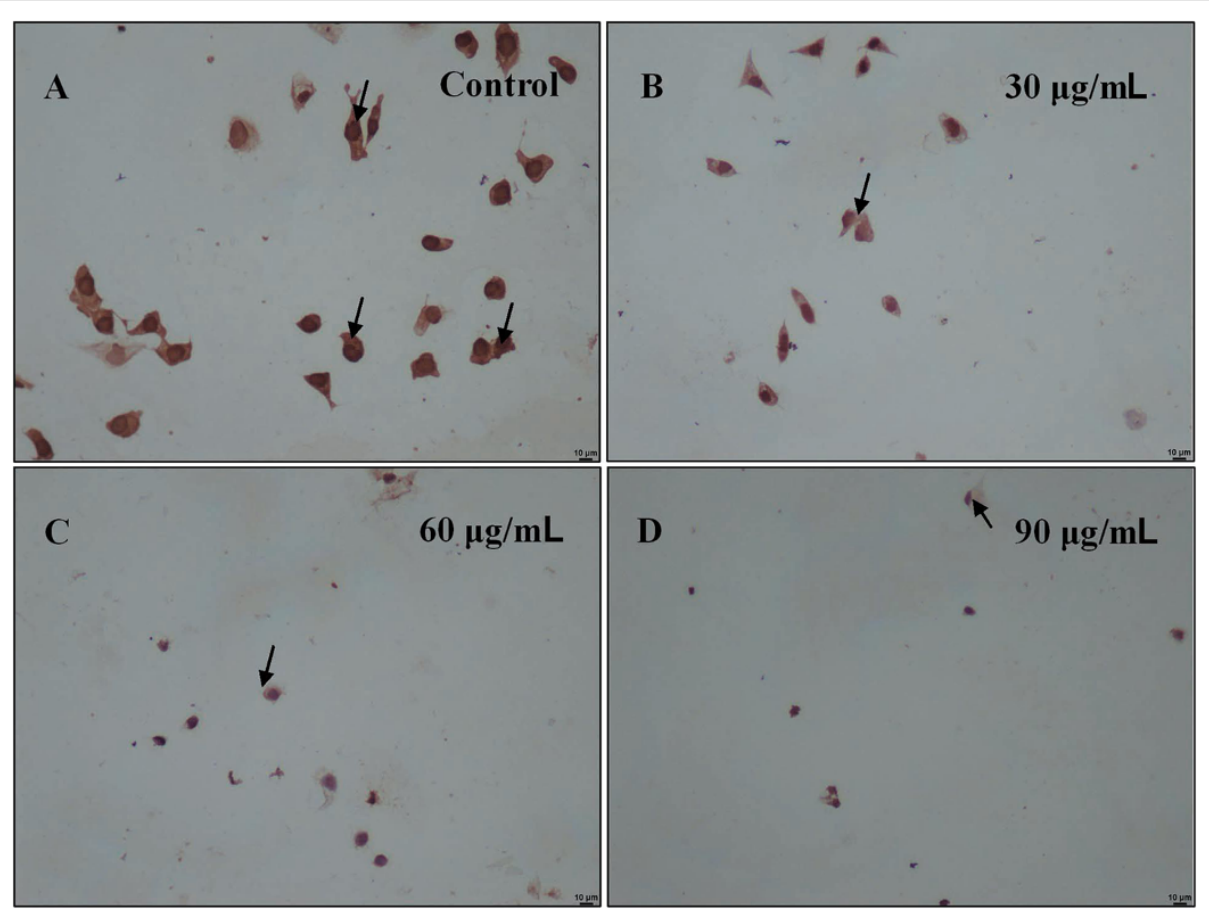

Figure 3 Zedoary oil downregulates PCNA protein expression in AGS cells. (A-D) Cells were treated with zedoary oil $(0,30,60 \mathrm{and} 90 \mu \mathrm{gg} / \mathrm{mL})$ for $24 \mathrm{~h}$, respectively. The brown color represents positive expression of PCNA protein. The blue color represents the cell nuclei of AGS cells (200x). The control cells were AGS cells cultured in Ham's/F-12 medium containing 10\% FBS and 0.1\% DMSO. 

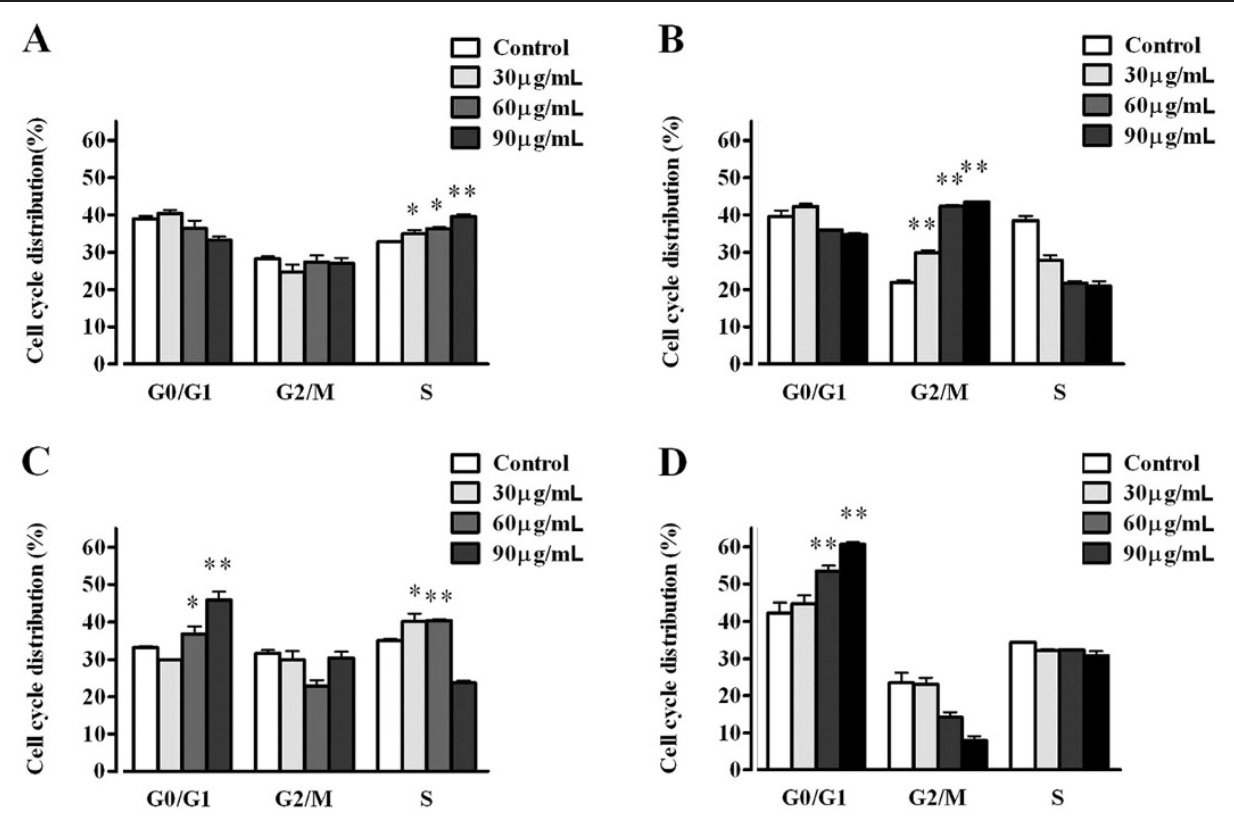

E

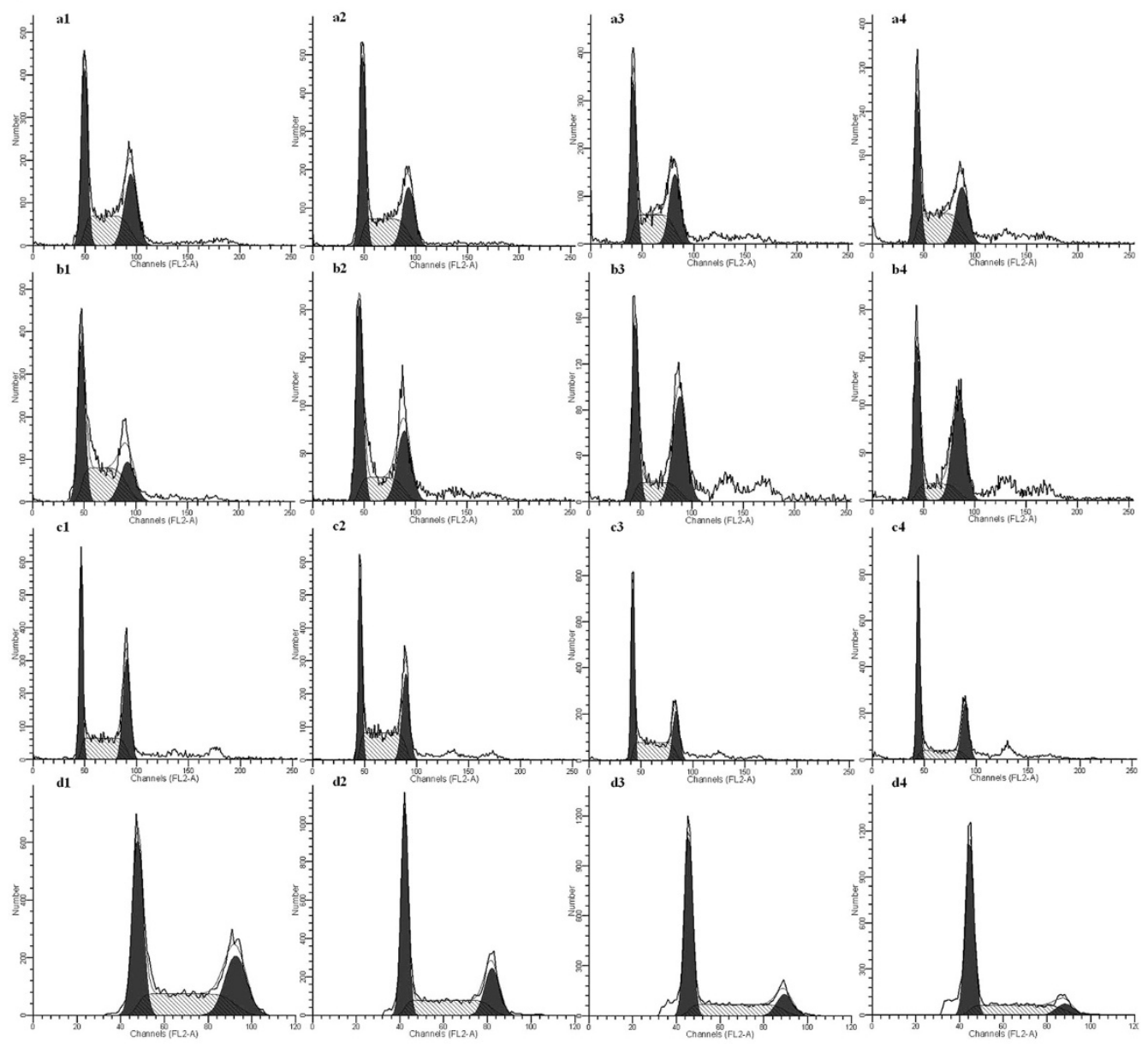

Figure 4 (See legend on next page.) 
(See figure on previous page.)

Figure 4 Zedoary oil induces cycle arrest in AGS cells. Zedoary oil was added at the indicated concentrations and the cells were incubated for $6,12,24$ and $48 \mathrm{~h}$. The cell cycle proportions were determined by flow cytometry after staining with PI. (A-D) Statistical analyses of the cell cycle phase distributions after 6, 12, 24 and 48 h, respectively. (E) Typical pictures of the respective cell cycle phase distributions from flow cytometry: a1-a4, control, 30, 60 and $90 \mu \mathrm{g} / \mathrm{mL}$ for 6 h; b1-b4, control, 30, 60 and $90 \mu \mathrm{g} / \mathrm{mL}$ for 12 h; c1-c4, control, 30, 60 and $90 \mu \mathrm{g} / \mathrm{mL}$ for $24 \mathrm{~h}$; d1-d4, control, 30, 60 and $90 \mu \mathrm{g} / \mathrm{mL}$ for $48 \mathrm{~h}$. The data represent means $\pm \mathrm{SD}\left({ }^{*} P<0.05,{ }^{*} P<0.01 \mathrm{vs}\right.$. control cells). The control cells were AGS cells cultured in Ham's/F-12 medium containing 10\% FBS and 0.1\% DMSO.

transferred onto Hybond-NC membranes by wet transfer. Subsequently, the NC membranes were blocked with $5 \%$ non-fat milk solution and incubated with the primary antibodies against Bax, Bcl-2 and $\beta$-actin overnight at $4^{\circ} \mathrm{C}$. After washing with $1 \times \mathrm{TBST}$, the NC membranes were incubated with goat anti-rabbit IgG (HuaAn, China). The protein bands were visualized with the ECL plus Kit, scanned and analyzed with SmartView software (Furi, China).

\section{Statistical analysis}

The data were represented by the mean \pm standard deviation (SD). Significant differences among three or more data sets were analyzed by one-way ANOVA with Dunnett's test using PrismDemo 4 software (GraphPad Software Inc., USA). Differences between two groups were analyzed by Student's $t$-test. The PrismDemo software did not provide exact $P$ values for ANOVA, and thus no exact $P$ values were reported. Values of $P<0.05$ were considered to indicate statistical significance.

\section{Results}

\section{GC-MS analysis of zedoary oil for quality control}

As shown in Figure 1 and Table 1, the GC-MS analysis detected 35 chemical compounds in zedoary oil. Curzerene (26.45\%), eucalyptol (12.04\%), curcumol (9.04\%), pyridine (7.97\%), germacrone $(7.89 \%), \beta$-elemene $(7.36 \%)$, т-elemene (4.11\%), curdione $(1.23 \%), \delta$-elemene $(1.05 \%),(-)$-alcanfor (3.18\%), camphene $(1.18 \%), 2-\beta$-pinene $(0.95 \%)$, bornylene (0.73\%), $\beta$-cubebene $(0.66 \%), \alpha$-caryophyllene $(0.6 \%)$ and $\alpha$-pinene $(0.67 \%)$ were indicated as the main compounds of essential oil of zedoary, whose relative contents (\% areas) were $>0.5 \%$ in the total zedoary oil. Many other compounds were also detected by the GC-MS, and several chemical compounds could not be determined from the NIST library.

\section{Inhibitory effects of zedoary oil on cell viability}

Zedoary oil inhibited the proliferation of AGS cells in a dose- and time-dependent manner after treatment for 24, 48 and $72 \mathrm{~h}(P<0.01$ vs. control cells) (Table 2$)$. The $\mathrm{IC}_{50}$ values of zedoary oil at 24,48 and $72 \mathrm{~h}$ were 72.40 , 64.28 and $63.83 \mu \mathrm{g} / \mathrm{mL}$, respectively.

Beta-elemene had inhibitory effects on AGS cell proliferation $(P<0.05, P<0.01$ for different concentration $v s$. control cells), and its $\mathrm{IC}_{50}$ values at 24,48 and $72 \mathrm{~h}$ were
280.57, 212.98 and $243.98 \mu \mathrm{g} / \mathrm{mL}$, respectively. Curcumol and curdione did not show significant inhibitory effects on AGS cell proliferation.

As shown in Figure 2, zedoary oil had significant inhibitory effects on the proliferation of MGC 803 cells. Zedoary oil increased the proliferation of GES-1 cells at 1,10 and $30 \mu \mathrm{g} / \mathrm{mL}$ from 24 to $48 \mathrm{~h}$. After $72 \mathrm{~h}$ of treatment, zedoary oil showed low inhibitory effects on cell proliferation. At the concentration of $60 \mu \mathrm{g} / \mathrm{mL}$, zedoary oil had low inhibitory effects on the viability of GES-1 cells. However, zedoary oil killed most of the AGS, MGC 803 and GES-1 cells at $90 \mu \mathrm{g} / \mathrm{mL}$.

In the presence of different FBS concentrations $(0,3$ and 10\%), zedoary oil achieved different inhibitory effects on the proliferation of AGS cells. There was a negative correlation between the FBS concentration and the inhibitory effect (Figure 2).

Inhibitory effects of zedoary oil on PCNA protein expression As shown in Figure 3, zedoary oil significantly decreased PCNA protein expression in AGS cells.

\section{Zedoary oil induces cell cycle arrest}

After treatment with zedoary oil at 60 and $90 \mu \mathrm{g} / \mathrm{mL}$ for $6 \mathrm{~h}$, the population of cells in $\mathrm{S}$ phase increased from 32.74 (in control cells) to $39.59 \%$ (in $90 \mu \mathrm{g} / \mathrm{mL}$-treated cells $)(P<0.05, P<0.01$ vs. control cells, respectively) (Figure 4A). After treatment for $12 \mathrm{~h}$, the populations of cells in $\mathrm{G}_{2} / \mathrm{M}$ phase reached 29.86 (in $30 \mu \mathrm{g} / \mathrm{mL}$-treated cells), 42.31 (in $60 \mu \mathrm{g} / \mathrm{mL}$-treated cells) and $43.41 \%$ (in $90 \mu \mathrm{g} / \mathrm{mL}$-treated cells), respectively, compared with $21.94 \%$ in the control group $(P<0.01, P<0.01, P<0.01$ vs. control cells) (Figure $4 \mathrm{~B})$. After treatment for $24 \mathrm{~h}$, the population of cells in $G_{0} / G_{1}$ phase was elevated from 33.20 (in control cells) to $45.88 \%$ (in $90 \mu \mathrm{g} / \mathrm{mL}$ treated cells) $(P>0.05, P<0.05, P<0.01$ vs. control cells $)$ (Figure $4 \mathrm{C}$ ), and the population of cells in $S$ phase increased from 35.08 (in control cells) to 40.19 (in $30 \mu \mathrm{g} / \mathrm{mL}-$ treated cells) and $40.40 \%$ (in $60 \mu \mathrm{g} / \mathrm{mL}$-treated cells) in zedoary oil-treated cells $(P<0.05, P<0.01 v s$. control cells), respectively. Zedoary oil (30, 60 and $90 \mu \mathrm{g} / \mathrm{mL})$ elevated the population of cells in $G_{0} / G_{1}$ phase from 42.25 (in control cells) to $60.64 \%$ (in $90 \mu \mathrm{g} / \mathrm{mL}$-treated cells) after treatment for $48 \mathrm{~h}(P>0.05, P<0.01, P<0.01 v s$. control cells, respectively) (Figure 4D). 


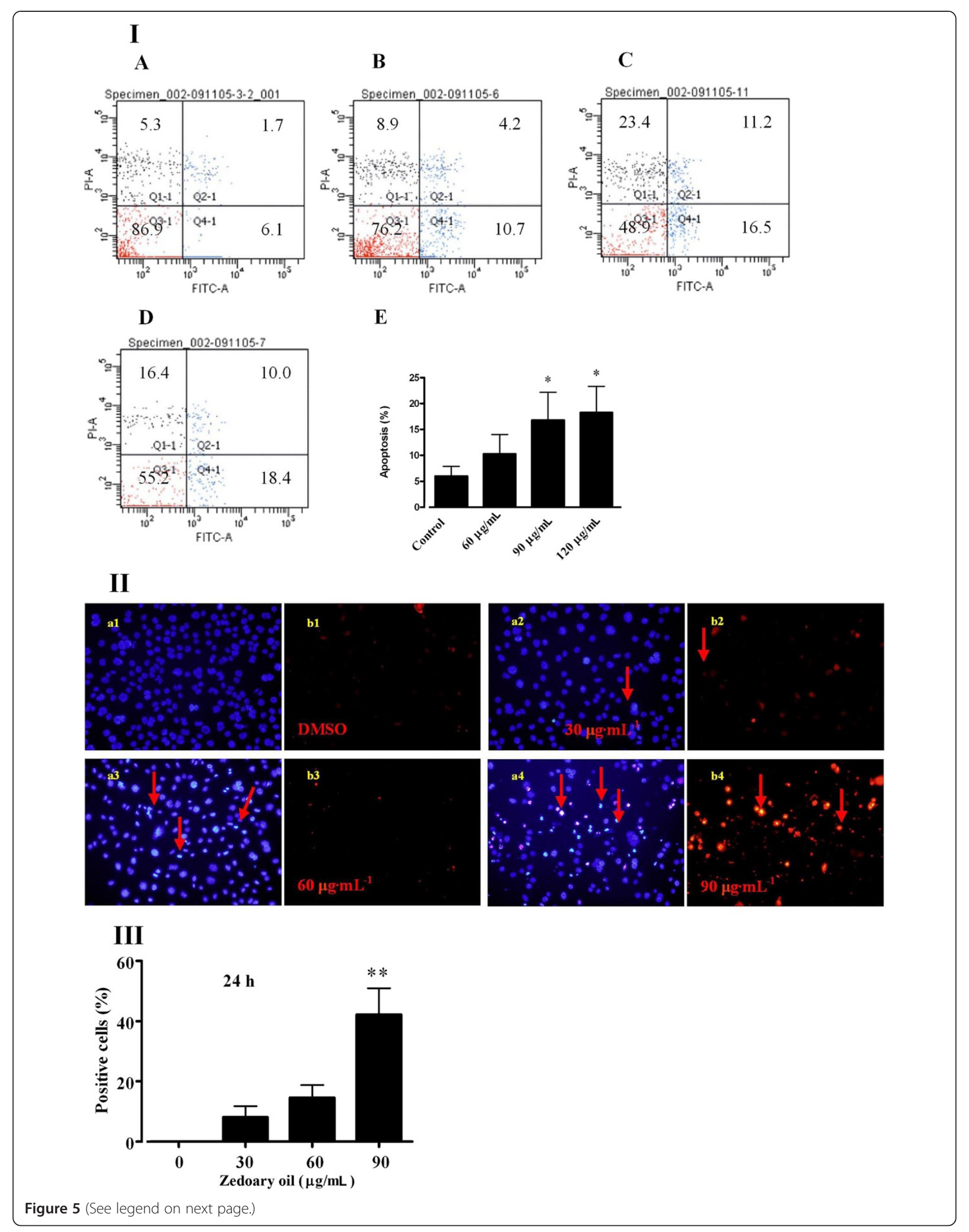


(See figure on previous page.)

Figure 5 Effects of essential oil of zedoary on cell apoptosis of AGS cells at 24 h. (IA) Control; (IB) $60 \mu \mathrm{g} / \mathrm{mL}$; (IC) $90 \mu \mathrm{gg} / \mathrm{mL}$; (ID) $120 \mu \mathrm{gg} / \mathrm{mL}$; (IE) effects of essential oil of zedoary on cell apoptosis evaluated by annexin V/PI double-staining at $24 \mathrm{~h}$. (II) Effects of zedoary oil on AGS cell apoptosis and necrosis evaluated by Hoechst 33342/PI double-staining for $24 \mathrm{~h}$ (200x). (III) Ratios of Hoechst 33342-positive cells whose blue color staining was brilliant and aggregative. The control cells were AGS cells cultured in Ham's/F-12 medium containing $10 \%$ FBS and $0.1 \%$ DMSO. ${ }^{*} P<0.05$, **P $<0.01$ vs. control cells.

\section{Zedoary oil induces cell apoptosis/necrosis}

Zedoary oil $(60,90$ and $120 \mu \mathrm{g} / \mathrm{mL})$ promoted the early cell apoptosis rate from 5.97 (in control cells) to $18.23 \%$ (in $120 \mu \mathrm{g} / \mathrm{mL}$-treated cells), as detected by flow cytometry with annexin V/PI double-staining $(P<0.05$ vs. control cells) (Figure 5I). The blue staining of Hoechst 33342, which crosses the cell membranes of both living and dying cells and stains their DNA, was of low intensity in untreated cells. However, the blue staining was brilliant and aggregative in treated cells, indicating that the DNA had become aggregative and that cell apoptosis was initiated after zedoary oil treatment. PI cannot penetrate the cell membranes of living cells, but can cross the cell membranes of dying cells and stain the DNA in the cell nucleus. Consequently, only late apoptotic and necrotic cells can be stained by PI. Thus, to distinguish late apoptotic and/or necrotic cells from early apoptotic cells, the numbers of Hoechst 33342-positive, but not PI-positive, cells were measured in this study. As shown in Figure 5, both cell apoptosis characteristics of brilliant and aggregative blue color staining were observed by Hoechst 33342/PI double-staining in zedoary oil-treated cells $(90 \mu \mathrm{g} / \mathrm{mL})$ for $24 \mathrm{~h}(P<0.01 v s$. control cells $)$.

\section{Protein expressions of Bcl-2 and Bax}

The western blot analyses revealed that the $\mathrm{Bcl}-2$ protein levels in AGS cells were significantly decreased by zedoary oil at 60,90 and $120 \mu \mathrm{g} / \mathrm{mL}$. Zedoary oil did not upregulate the Bax protein expression level at 60 and $90 \mu \mathrm{g} / \mathrm{mL}$, but did increase the Bax protein expression level at $120 \mu \mathrm{g} / \mathrm{mL}$. Moreover, zedoary oil at 90 and $120 \mu \mathrm{g} / \mathrm{mL}$ increased the ratio of $\mathrm{Bax} / \mathrm{Bcl}-2$ protein expression $(P<0.01 v s$. control cells) (Figure 6).

\section{Discussion}

Some zedoary varieties or origins do not contain curdione, curcumol and curzerenone [32-34]. Thus, it is important to determine the compounds in zedoary oil for its quality control [15].

A

$\begin{array}{llll}1 & 2 & 3 & 4\end{array}$
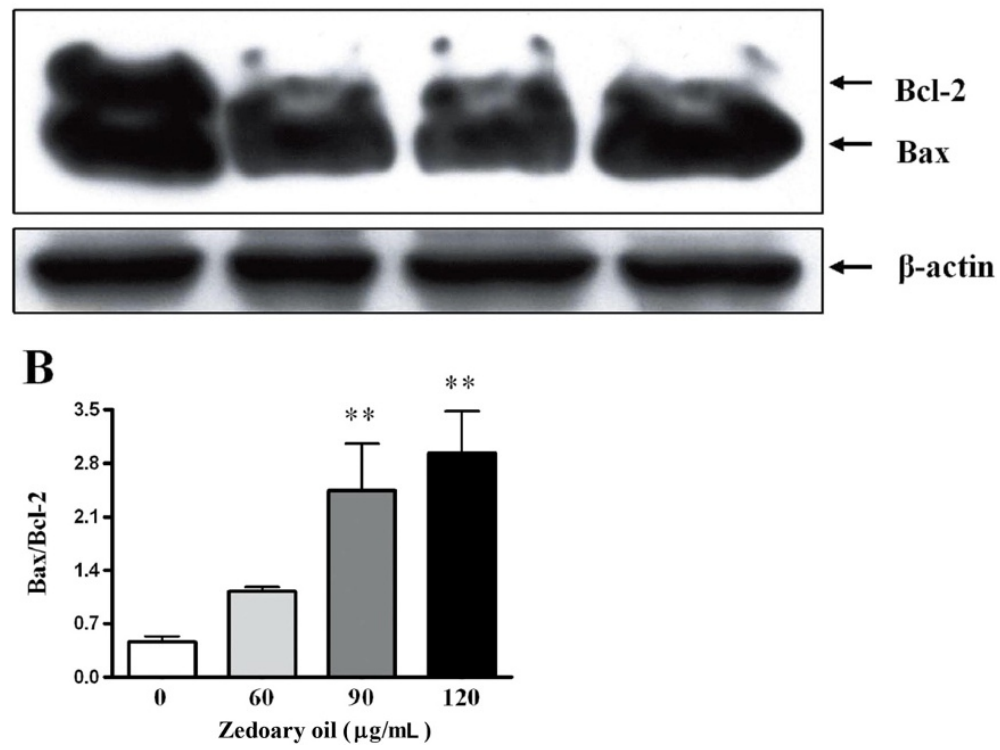

Figure 6 Effects of zedoary oil on apoptosis-related Bcl-2 and Bax protein expression in AGS cells. (A) Effects of zedoary oil on apoptosis-related protein Bcl-2 and Bax expression in AGS cells. The control cells were AGS cells cultured in Ham's/F-12 medium containing 10\% FBS and 0.1\% DMSO. The cells were incubated with zedoary oil for $24 \mathrm{~h}$, collected and measured for their Bax and Bcl-2 protein expression by western blot analysis. 1: control; 2: $60 \mu \mathrm{g} / \mathrm{mL} ; 3: 90 \mu \mathrm{g} / \mathrm{mL} ; 4: 120 \mu \mathrm{g} / \mathrm{mL}$. (B) Effects of zedoary oil on the ratio of Bax/Bcl-2 expression. 
In the present study, the GC-MS results showed that our zedoary oil contained curcumol, $\beta$-elemene, curdione and germacrone, which is a characteristic component of zedoary oil $[12,35]$. Zedoary oil was reported to show antitumor activities toward different human cancer cells and/or animal models with different malignant tumors, such as human oophoroma, hepatocellular carcinoma, lung cancer and leukemia, in vitro and in vivo [8-11,36]. However, the inhibitory effects of zedoary oil on chronic atrophic gastritis and gastric cancer have not been examined. In our study, inhibitory effects of zedoary oil on the viability of AGS cells and MGC 803 cells were observed. In previous studies [12,32], $\beta$-elemene, curcumol and curdione showed inconsistent results for antitumor activities. In the present study, $\beta$-elemene, but not curdione and curcumol, showed inhibitory effect on AGS cell proliferation. The ability of $\beta$-elemene to inhibit the proliferation of AGS cells was weaker than that of zedoary oil. These findings indicate that other compounds in zedoary oil might have inhibitory effects on AGS cell viability, or that many ingredients may have a synergistic inhibitory effect on AGS cell proliferation, which should be investigated in further studies. Although more than 30 compounds were detected in zedoary oil, we were unable to identify all the compounds and determine the active compounds involved in the inhibition of AGS cell proliferation, owing to time and cost issues.

In this study, zedoary oil had stronger inhibitory effects on AGS cell proliferation in the presence of lower FBS concentrations (0 and $3 \%)$. These observations may indicate that some FBS ingredients (e.g., esterases) rapidly break down the active ingredients in zedoary oil, thereby decreasing the inhibitory effects of zedoary oil on the growth of gastric cancer cells. Furthermore, AGS cells may be weaker and more sensitive to chemical compounds because of the lack of nutrition at lower concentrations of FBS $[37,38]$. We did not investigate the causes of the differences in the inhibitory effects of zedoary oil between the presence and absence of FBS, because cancer cells always exist in a nutrition-rich environment. Zedoary oil showed weaker inhibitory effects on MGC 803 cells than on AGS cells in medium containing 3\% FBS, because of differences between the two cell lines.

In our investigations, zedoary oil induced cell cycle arrest at $S, G_{2} / M$ and $G_{0} / G_{1}$ phases at different times during 6$48 \mathrm{~h}$ of treatment. Other compounds, such as tangeretin and nobiletin, have similar effects on the cell cycle [39]. After treatment for 6 and $12 \mathrm{~h}$, cell cycle arrest was induced by zedoary oil at concentrations of 30 and $60 \mu \mathrm{g} / \mathrm{mL}$, which did not have obvious inhibitory effects on AGS cell proliferation. Cell cycle arrest at 6-12 h may result in DNA repair in AGS cells, with a view to escaping from cell apoptosis/ necrosis. Subsequently, after treatment with zedoary oil for $24 \mathrm{~h}$, the cells whose DNA could not be repaired proceeded to cell apoptosis/necrosis, which was confirmed by observations of apoptotic/necrotic characteristics detected by flow cytometry and Hoechst 33342/PI double-staining in zedoary oil-treated AGS cells.

In our experiments, PCNA protein expression in AGS cells was significantly downregulated by zedoary oil treatment. This finding confirmed that zedoary oil inhibited AGS cell proliferation.

Zedoary oil induces cell apoptosis through a mitochondria/ caspase-dependent pathway in human hepatoma cells [10]. In the present study, zedoary oil significantly decreased Bcl-2 protein expression and decreased Bax protein expression in $60 \mu \mathrm{g} / \mathrm{mL}$ zedoary oil-treated cells, while the Bax protein level in $120 \mu \mathrm{g} / \mathrm{mL}$ zedoary oil-treated cells was increased, indicating that the balance between Bax and Bcl-2 in cytochrome c-dependent apoptosis was disturbed.

\section{Conclusions}

Zedoary oil inhibited AGS cell proliferation through cell cycle arrest and cell apoptosis promotion, which were related to $\mathrm{Bax} / \mathrm{Bcl}-2$ protein expression.

\section{Abbreviations}

DMSO: Dimethyl sulfoxide; PI: Propidium iodine; FBS: Fetal bovine serum; MTT: 3-(4,5-dimethylthizol-2-yl)-2,5-diphenyltetrazolium bromide; TBST: Tris-HCl-buffered saline with 0.1\% Tween-20; SDS-PAGE: Sodium dodecyl sulfate-polyacrylamide gel electrophoresis; GC-MS: Gas chromatography-mass spectrometry; GC: Gas chromatography; NIST: National Institute of Standards and Technology; PBS: Phosphate-buffered saline; NC: Nitrocellulose; RT: Retention time; PCNA: Proliferating cell nuclear antigen.

\section{Competing interests}

The authors declare that they have no competing interests.

\section{Authors' contributions}

GJ and JX designed the study. HS, BT, LL, SS and AC performed the experiments. HS, BT, GJ and JX wrote the manuscript. All authors read and approved the final manuscript.

\section{Acknowledgments}

This project was supported by the High Level Project of University of Educational Commission of Shanghai of China (No. 2008GSP19), Opening Project of Shanghai Key Laboratory of Complex Prescription (No,

11DZ2272300), Educational Commission of Shanghai of China (No. 09JW21 and 2012JW19), Shanghai Leading Academic Discipline Project (No. J50305) and Shanghai Municipal Natural Science Foundation (No. 09ZR1431800).

\section{Author details}

${ }^{1}$ Institute of Digestive Disease, Longhua Hospital, Shanghai University of Traditional Chinese Medicine, 725 South Wanping Road, XuHui District, Shanghai 200032, PR China. ${ }^{2}$ Institute of Materia Medica, Shanghai University of Traditional Chinese Medicine, 1200 Cailun Road, Zhangjiang Hi-tech Park, Shanghai 201203, PR China. 3Shanghai Key Laboratory of Complex Prescription, 1200 Cailun Road, Zhangjiang Hi-tech Park, Shanghai 201203, PR China. ${ }^{4}$ Chinese Medicine Hospital of Shanxi Province, Taiyuan, Shanxi Province 030012, PR China.

Received: 19 May 2012 Accepted: 9 June 2013

Published: 28 June 2013

\section{References}

1. Pharmacopeia Commission of PRC: Pharmacopoeia of the People's Republic of China (English edition). Beijing: Chemical Industry Press; 2000:230. 
2. Wilson B, Abraham G, Manju VS, Mathew M, Vimala B, Sundaresan S, Nambisan B: Antimicrobial activity of Curcuma zedoaria and Curcuma malabarica tubers. J Ethnopharmacol 2005, 99:147-151.

3. Uechi S, Ishimine $Y$, Hong F: Antibacterial activity of essential oil derived from Curcuma zedoaria against food borne pathogenic bacteria and their thermal stability. Rdngbm 2000, 47:129-136.

4. Wang YF, Liu SQ, Zhao JH: Observation of therapeutic effect of Compound Zedoary Turmeric Oil Suppositories for treating monilial vaginitis with pregnancy. Hebei Yi Yao (Chin) 2006, 28:839-840.

5. Ding $Y L, X u A X$ : Effects of oil of Zedoary and its valid component against tumor. Zhong Yao Cai (Chin) 2005, 28:152-156.

6. He JS: Clinic application of oil of Zedoary in paediatrics. Xiandai Zhong Xi Yi Jie He Za Zhi (Chin) 2006, 15:501.

7. Ding XL, Hu LC: Therapeutic effect of injection of Zedoary oil on viral myocarditis in paediatrics. Shizhen Guo Yi Guo Yao (Chin) 2002, 13:670-671.

8. Li X, Wang G, Zhao J, Ding H, Cunningham C, Chen F, Flynn DC, Reed E, Li QQ: Antiproliferative effect of $\beta$-elemene in chemoresistant ovarian carcinoma cells is mediated through arrest of the cell cycle at the G2-M phase. Cell Mol Life Sci 2005, 62:894-904.

9. Wu WY, Xu Q, Shi LC, Zhang WB: Inhibitory effects of Curcuma aromatica oil on proliferation of hepatoma in mice. World J Gastroenterol 2000, 6:216-219.

10. Xiao Y, Yang FQ, Li SP, Hu G, Li SMY, Wang YT: Essential oil of Curcuma wenyujin induces apoptosis in human hepatoma cells. World J Gastroenterol 2008, 14:4309-4318.

11. Zhao J, Li QQ, Zou B, Wang G, Li X, Kim JE, Cuff CF, Huang L, Reed E, Gardner K: In vitro combination characterization of the new anticancer plant drug $\beta$-elemene with taxanes against human lung carcinoma. Int J Oncol 2007, 31:241-252.

12. Li GD, Xu F, Shen AJ: Research advances for zedoary turmeric oil. Zhong Guo Yao Xue Za Zhi (Chin) 2002, 37:806-809.

13. Deng $S, M o L$, Ou Y, Ou R: Experimental study of the acute toxicity of the zedoary turmeric oil gelatin microsphere. Yi Yao Dao Bao (Chin) 2002, 21:200-202.

14. Yang FQ, Wang YT, Li SP: Simultaneous determination of 11 characteristic components in three species of Curcuma rhizomes using pressurized liquid chromatography. J Chromatogr A (Chin) 2006, 1134:226-231.

15. Xiang X, Lü G, Chen S, Lou Z: Progress in research of quality control and pharmacological actions in essential oil of Curcuma. Zhonguo Xian Dai Ying Yong Yao Xue (Chin) 2010, 27:979-982.

16. Correa P, Piazuelo MB, Camargo MC: The future of gastric cancer prevention. Gastric Cancer 2004, 7:9-16.

17. El-Zimaity HM, Ota H, Graham DY, Akamatsu T, Katsuyama T: Patterns of gastric atrophy in intestinal type gastric carcinoma. Cancer 2002, 94:1428-1436.

18. El-Zimaity H: Gastritis and gastric atrophy. Curr Opin Gastroenterol 2008, 24:682-686.

19. Kuipers EJ: Review article: Relationship between Helicobacter pylori, atrophic gastritis and gastric cancer. Aliment Pharmacol Ther 1998, 12:25-36.

20. Leonardi E, Girlando S, Serio G, Mauri FA, Perrone G, Scampini S, Dalla Palma P, Barbareschi M: PCNA and Ki 67 expression in breast carcinoma: correlations with clinical and biological variable. J Clin Pathol 1992 4:416-419.

21. OW YP, Green DR, Hao Z, Mak TW: Cytochrome c: functions beyond respiration. Nat Rev Mol Cell Biol 2008, 9:532-542.

22. Xu Y, Ge R, Du J, Xin H, Yi T, Sheng J, Wang Y, Ling C: Corosolic acid induces apoptosis through mitochondrial pathway and caspases activation in human cervix adenocarcinoma HeLa cells. Cancer Lett 2009, 284:229-237.

23. Reyes-Zurita FJ, Rufino-Palomares EE, Lupianez JA, Cascante M: Maslinic acid, a natural triterpene from Olea europaea L., induces apoptosis in HT29 human colon-cancer cells via the mitochondrial apoptotic pathway. Cancer Lett 2009, 273:44-54.

24. Das A, Banik NL, Ray SK: Mechanism of apoptosis with the involvement of calpain and caspase cascades in human malignant neuroblastoma $\mathrm{SH}$ SY5Y cells exposed to flavonoids. Int J Cancer 2006, 119:2575-2585.

25. El-Mahdy MA, Zhu Q, Wang QE, Wani G, Wani AA: Thymoquinone induces apoptosis through activation of caspase- 8 and mitochondrial events in p53-null myeloblastic leukemia HL-60 cells. Int J Cancer 2005, 117:409-417.
26. Lin J, Huang WW: A systematic review of treating Helicobacter pylori infection with traditional Chinese medicine. World J Gastroenterol 2009, 15:4715-4719

27. Liu W, Hao WW, Zhu LY, Gong YP, Tang ZP, Wang ZN: Clinical efficacy of "Weiqi Beverage" in treating functional dyspepsia and its effects on motilin. Shanghai Zhong Yi Yao Za Zhi (Chin) 2008, 42:36-38.

28. Hu HY, Zheng HB, Lu X, Gong YP, Ma GT: Mechanism of the effects of "Weiqiyin Drink" in reversing chronic atrophic gastritis. Zhongguo Zhong Xi Yi Jie He Xiao Hua Za Zhi (Chin) 2001, 9:94-96.

29. Tan B, Shi HL, Ji G, Lu L, Cao AL, Shi SS, Xie JQ: Antiproliferative effects of essential oil of a compound Chinese herbal medicine Weiqi Decoction on AGS cells. J Chin Integr Med 2011, 9:558-564.

30. Kim JM, Kim KM, Park EH, Seo JH, Song JY, Shin SC, Kang HL, Lee WK, Cho MJ, Rhee $\mathrm{KH}$, Youn HS, Baik SC: Anthocyanins from black soybean inhibit Helicobacter pylori-induced inflammation in human gastric epithelial AGS cells. Microbiol Immunol 2013. doi:10.1111/j.1348-0421.12049.

31. Liu W, Chen Y, Lu G, Sun L, Si J: Down-regulation of HSP70 sensitizes gastric epithelial cells to apoptosis and growth retardation triggered by H. pylori. BMC Gastroenterol 2011, 11:146.

32. Wang Y, Wang MZ: Study on the quality of Rhizoma Curcumae. Zhong Guo Yao Li Xue Bao (Chin) 2001, 36:849-853.

33. Xie $Y$, Hang T, Zhang $X$, An D: Comparison of curcumol contents in essential oil from four species of rhizome Curcumae L. Zhong Cao Yao (Chin) 2001, 32:600-602.

34. Pisani P, Parkin DM, Bray F, Ferlay J: Estimates of the worldwide mortality from 25 cancers in 1999. Int J Cancer 1999, 83:18-29.

35. Li QF, Shi HJ: Study on the methods of quality control of Rhizoma Curcumae. Zhong Guo Zhong Yao Za Zhi J Chin Med Mater (Chin) 2004, 27:526-527.

36. Yu Z, Wang R, Xu L, Dong J, Jing Y: N-(beta-Elemene-13-yl) tryptophan methyl ester induces apoptosis in human leukemia cells and synergizes with arsenic trioxide through a hydrogen peroxide dependent pathway. Cancer Lett 2008, 269:165-173.

37. Satoh H, Ishikawa H, Fujiwara M, Yamashita YT, Ohtsuka M, Ogata T, Hasegawa S, Kamma H: Production of cytokeratin 19 fragment by human squamous lung cancer cell lines. Am J Respir Cell Mol Biol 1997, 16:597-604.

38. Ghazi NA, Hussain KIA, Malek NANN, Hamdan S: The effects of zeolite X and $Y$ on cancer cell lines. J Sci Technol 2012, 4:33-40.

39. Morley KL, Ferguson PJ, Koropatnick J: Tangeretin and nobiletin induce G1 cell cycle arrest but not apoptosis in human breast and colon cancer cells. Cancer Lett 2007, 251:168-178.

doi:10.1186/1749-8546-8-13

Cite this article as: Shi et al:: Zedoary oil (Ezhu You) inhibits proliferation of AGS cells. Chinese Medicine 2013 8:13

\section{Submit your next manuscript to BioMed Central and take full advantage of:}

- Convenient online submission

- Thorough peer review

- No space constraints or color figure charges

- Immediate publication on acceptance

- Inclusion in PubMed, CAS, Scopus and Google Scholar

- Research which is freely available for redistribution 